\title{
EVALUATION OF VITAL STAINS FOR FREE-LIVING MARINE NEMATODES
}

\author{
Micheli Cristina Thomas ${ }^{*}$ and Paulo da Cunha Lana \\ Universidade Federal do Paraná - UFPR \\ Laboratório de Bentos, Centro de Estudos do Mar, Setor de Ciências da Terra \\ (Av. Beira-mar, 83255-000 Pontal do Paraná, PR, Brasil) \\ *E-mail: michelithomas@ufpr.br
}

Because of their small size and life-history traits, meiofaunal organisms, such as free-living nematodes, are useful biological tools for lab or field experiments (AUSTEN; SOMERFIELD, 1997; SCHRATZBERGER et al., 2000; ULLBERG; ÓLAFSSON, 2003; SOMERFIELD et al., 2005). Conventional staining techniques, usually after fixation, are still useful to facilitate their extraction or recuperation from the sediment. For example, nematodes are well seen with Bengal Rose after fixation with $4 \%$ formaline. Bengal Rose stains the protoplasm, which helps to identify live animals at the time of fixation and to remove them from the sediment (WALTON, 1952). On the other hand, vital staining methods are a prerequisite for studying biological processes when animals have to be kept alive. Radioactive and fluorescent pigments are often used as vital markers for feeding studies (DE NIRO; EPSTEIN, 1978; EPSTEIN; SHIARIS, 1992; STARINK et al., 1994; HAMELS et al., 2001). However, vital staining techniques for the assessment of mobility strategies or dispersal rates are virtually unknown in the case of benthic nematodes, copepods and other meiofaunal taxa.

To establish reliable protocols to mark freeliving nematodes, we tested the adequacy of a set of easily available vital stains, commonly used for histological work, including Bromothymol Blue, Methylene Blue, Toluidine Blue, Trypane Blue, Neutral Red and Methyl Violet.

Vital staining agents act by accumulating in specific parts of cells due to their electric charge. Electro-positive agents are basic, and electro-negative agents are acid, and therefore tend to accumulate in tissues or structures that are of the reverse charge (SANDERSON, 1994). Bromothymol Blue acts as a weak acid in solution and may be found in both acidic and basic forms, with their respective yellow or blue colors (green in neutral solutions). Methylene Blue is an aniline-derived basic stain that colors the nucleus blue, and may be used to show mucilagenous and cartilagenous tissues and defense cells. Toluidine Blue is also an aniline derivative, also metachromatic, and used to show nuclei and mastocyte granules. Trypane Blue is used to distinguish viable and inviable cells (LLEWELLY, B., http://stainsfile.info/StainsFile/index.html). Neutral Red, a basic stain, acts in live cells, passing the cell membrane and being captured by endocytosis in its fluid phase, from which it passes into lysosomes and endosomes (both acidic) where it turns yellow through proteination (CHU et al., 2002). Methyl Violet (Gentian Violet) is a basic stain and an active ingredient in the Gram stain used in bacterial research. It is metachromatic and may be used to stain starch and other similar substances.

Nematodes used in this study were collected in September 2005 in the Perequê tidal creek (Pontal do Paraná, Paraná, Brazil). They were kept alive in water taken from the same field location at the Benthos Laboratory of the Center for Marine Studies of the Federal University of Paraná.

Nematodes were retrieved by gently washing the sediments through a $63 \mu \mathrm{m}$ filter, and later analysed with a stereoscopic microscope (UHLIG et al., 1973). Animals were separated into Petri dishes with $1 \mathrm{ml}$ sea water and divided into three treatments: control (sea water without stain), $0.5 \mathrm{ml}$ and $1.0 \mathrm{ml}$ of each tested stain. Five nematodes were used per treatment and observed in Petri dishes at 0, 30, 60 and 180 minutes after application of the stain.

Vital staining agents, while always toxic depending upon the concentrations, should not cause damage to the organisms when adequately diluted. To avoid potential problems, vital staining agents are usually applied in very dilute form, varying between 1:5.000 and 1:500.000 (HOWEY, 2000). Initial concentration was that conventionally used for histological purposes, which vary among the selected stains. The actual concentration of the stain was calculated by incorporating the volume to which the stain was added (Table 1).

To evaluate the potential effects of the stains, which may affect mobility and feeding strategies of nematodes (HIGGINS, 1988), each treatment was compared to the control. Considering the low number of tested animals, no significance tests were applied, and stain adequacy was grossly estimated as nematode survival rates, expressed as percentage, 180 minutes after staining.

General patterns of mobility and reaction to mechanical and light stimuli were used as criteria to evaluate nematode behavior at each treatment. All control animals survived without any apparent behavior changes at the end of the experiment. 
Table 1. Final tested concentration of each stain as calculated by incorporating the volume to which the stain was added. Initial stain concentration in parenthesis.

\begin{tabular}{ccccccc}
\hline \hline \multicolumn{1}{c}{ Stains } \\
\hline \multirow{2}{*}{ Treatments } & $\begin{array}{c}\text { Methylene } \\
\text { Blue (0.05) }\end{array}$ & $\begin{array}{c}\text { Toluidine Blue } \\
(0.025)\end{array}$ & $\begin{array}{c}\text { Trypane } \\
\text { Blue }(0.05)\end{array}$ & $\begin{array}{c}\text { Neutral } \\
\text { Red } \\
(0.01)\end{array}$ & $\begin{array}{c}\text { Methyl } \\
\text { Violet }(0.02)\end{array}$ & $\begin{array}{c}\text { Bromothymol } \\
\text { Blue }(0.02)\end{array}$ \\
$\mathbf{0 . 5} \mathbf{~ m l}$ & 0.016 & 0.008 & 0.016 & 0.003 & 0.060 & 0.060 \\
$\mathbf{1 . 0 ~} \mathbf{~ m l}$ & 0.025 & 0.013 & 0.025 & 0.005 & 0.100 & 0.100 \\
\hline
\end{tabular}

Bromothymol Blue, Methyl Violet, Trypane Blue, and Toluidine Blue at both concentrations were not adequate stains, since all animals were killed after 180 minutes of exposure. The mouth, teeth and internal parts of the body got greenish hued with Bromothymol Blue at $0.06 \%$, while the cuticle was light green. At $0.1 \%$ concentration, the color was much more pronounced and it became impossible to discriminate any internal structures. Methyl Violet gave the animals an accentuated purple color, at both concentrations, very obvious in the cuticle (stronger anteriorly and posteriorly) and in the digestive tube.

Nematode survival rates for Methylene Blue were $80 \%$ and $60 \%$ for each tested concentration at
180 minutes after staining. Though nematode behavior was only partially affected, Methylene Blue stained the animals so much at high concentrations that it hided the internal organs.

Neutral Red caused no mortality at either concentration (Table 2). It caused no apparent changes in behavior, and effectively stained internal structures and cuticles of the tested nematodes, though not as well at low as at higher concentrations. In the low concentration treatment, several granular, internal objects (probably inclusions) were stained. In the high concentration treatment, the entire subcuticular region was stained, including cells of the hypodermis.

Table 2. Animal survival rates (in percentage) after application of each stain in low and high concentrations. Columns indicate the actual number of live animals after each time interval for each treatment. All animals survived in the control treatment.

\begin{tabular}{|c|c|c|c|c|c|c|c|c|c|c|c|c|}
\hline \multirow[b]{2}{*}{ Time (minutes) } & \multicolumn{2}{|c|}{$\begin{array}{c}\text { Methylene } \\
\text { Blue }\end{array}$} & \multicolumn{2}{|c|}{ Toluidine Blue } & \multicolumn{2}{|c|}{ Trypane Blue } & \multicolumn{2}{|c|}{ Neutral Red } & \multicolumn{2}{|c|}{ Methyl Violet } & \multicolumn{2}{|c|}{$\begin{array}{c}\text { Bromothymol } \\
\text { Blue }\end{array}$} \\
\hline & Low & High & Low & High & Low & High & Low & High & Low & High & Low & High \\
\hline $\mathbf{0}$ & 5 & 5 & 4 & 4 & 5 & 5 & 5 & 5 & 2 & 3 & 1 & 2 \\
\hline 30 & 5 & 5 & 3 & 4 & 5 & 4 & 5 & 5 & 2 & 3 & 0 & 0 \\
\hline 60 & 5 & 5 & 0 & 0 & 5 & 4 & 5 & 5 & 2 & 0 & 0 & 0 \\
\hline 180 & 4 & 3 & 0 & 0 & 4 & 4 & 5 & 5 & 0 & 0 & 0 & 0 \\
\hline Total Living & 4 & 3 & 0 & 0 & 0 & 0 & 5 & 5 & 0 & 0 & 0 & 0 \\
\hline Survival (\%) & 80 & 60 & 0 & 0 & 0 & 0 & 100 & 100 & 0 & 0 & 0 & 0 \\
\hline
\end{tabular}


Neutral Red has been used as a vital stain to visualize pseudopod movement or cyclosis (MAIA, 1979) and endocytosis and the vacuole system in oysters (CHU et al., 2002). Inclusions, such as celomocytes, which occur in the body cavity and in the hypodermis of nematodes, may have secretive or absorptive properties and also tend to be stained with Neutral Red (LEE, 1956). The cuticle is physiologically active and probably supported by the hypodermis which is also active during moulting (BIRD; BIRD, 1991).

We recommend the use of Neutral Red in $0.005 \%$ concentration as a vital stain for nematodes in bioassays, experimental laboratory and field studies, as well as behavioral studies of these animals. This stain is rapid acting, makes the animals readily apparent and does not hide internal structures. It also seems to be adequate for other meiofaunal organisms, such as copepods and polychaete larvae (personal observations). Careful handling and disposal of Neutral Red is also recommended, since there are indications that it may have carcinogenic and mutagenic properties (HOWEY, 2000).

\section{ACKNOWLEDGEMENTS}

We thank Prof. Ruth Janice Guse Schadeck, and the Fungus Biotechnology laboratory of the Departament of Cell Biology at the Federal University of Paraná, for providing some of the stains and for a number of useful comments. Prof. James Ropper translated an original Portuguese version into English.

\section{REFERENCES}

AUSTEN, M. C.; SOMERFIELD, P. J. A community leve sediment bioassay applied to an estuarine heavy metal gradient. Mar. environ. Res., v. 43, p. 315-328, 1997.

BIRD, A. F.; BIRD, J. The Structure of Nematodes. San Diego: Academic Press, 1991.316 p.

CHU, F. L. E.; VOLETY, A. K.; HALE, R. C.; HUANG, Y. Cellular responses and disease expression in oysters (Crassostea virginica) exposed to suspended fieldcontaminated sediments. Mar. environ. Res., v. 53, p. $17-35,2002$

DE NIRO, M. J.; EPSTEIN, S. S. Influence of diet on distribution of carbon isotopes in animals. Geochim. Cosmochim. Acta, v. 42, p.495-506, 1978.
EPSTEIN, S. S.; SHIARIS, M. P. Rates of microbenthic and meiobenthic bacterivory in a temperate muddy tidal flat community. Appl. environ. Microbiol., v. 58:, p. 24262431, 1992.

HAMELS, I.; MUYLAERT, K.; CASTELEYN, G.; VYVERMAN, W. Uncoupling of bacterial production and flagellate grazing in aquatic sediments: a case study from an intertidal flat. Aquat. Microbial Ecol., v. 25, p. 31-42, 2001.

HIGGINS, R. P.; THIEL, H. Introduction to the study of Meiofauna. Washington, D.C.: Smithsonian Institution Press, 1988. 488 p.

HOWEY, R. L. Vital staining for Protozoa and related temporary mounting techniques. 2000. $<$ http://www.microscopy.uk.org.uk/mag/indexmag.html? http://www.microscopyuk.org.uk/mag/artfeb00/rhvital.ht $\mathrm{ml}>$

LEE, D. L. The physiology of Nematodes. Edinburgh;London: Oliver \& Boyd, 1965. 154 p. University Reviews in Biology: 3.

LLEWELLY, B.<http://stainsfile.info/StainsFile/index.html> MAIA, V. 1979. Técnica histológica. $2^{2}$. ed. São Paulo: Atheneu, 1979. $246 \mathrm{p}$.

SANDERSON, J. B. Biological microtechnique. Preston: BIOS Scientific Publishers, 1994. 224 p.

SCHRATZBERGER, M.; REES, H. L. BOYD, S. E. Effects of simulated deposition of dredged material on structure of Nematode assemblages - the role of contamination. Mar. Biol., v. 137, p. 613-622, 2000.

SOMERFIELD, P. J; WARWICK, R. M.; MOENS, T. Meiofauna Techniques. In: ELEFTHERIOU, A.; MCINTYRE, A. (Ed.). Methods for study of marine Benthos. 3rd ed. Oxford; Malden,MA: Blackwell Science, 2005. p. 229-245.

STARINK, M.; KRYLOVA, I. N.; BARGILISSEN, M. J.; BAK, R. P. M.; CAPPENBERG, T. E. Rates of benthic protozoan grazing on free and attached sediment bacteria measured with fluorescently stained sediment. Appl. environ. Microbiol.,v. 60:, p. 2259-2264, 1994.

UHLIG, G.; THIEL, H. ; GRAY, J. S. The quantitative separation of meiofauna: A comparison of methods. Helgolander Meeresunters., v. 25, p. 173-195, 1973.

ULLBERG, J.; ÓLAFSSON, E. Free-living marine nematodes actively choose habitat when descending from the water column. Mar. Ecol.Prog. Ser., v. 260: 141-149, 2003

WALTON, M. Techiniques for recognition of living foraminifera. Contr. Cushman Fdn. foram. Res., v. 3, p. $56-60,1952$.

(Manuscript received 30 May 2007; revised 04 September 2007; accepted 12 November 2007) 